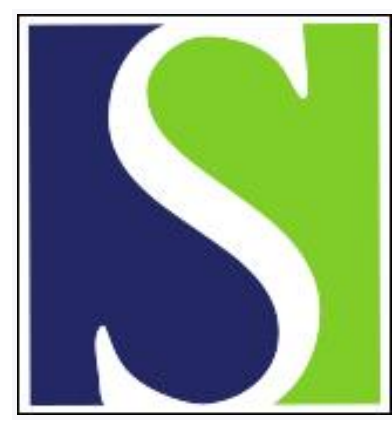

Scand J Work Environ Health 2006;32(1):5-11

https://doi.org/10.5271/sjweh.970

Issue date: 31 Feb 2006

\title{
Cost of obesity in the workplace
}

by Schmier J, Jones ML, Halpern MT

Affiliation: Jordana Schmier, 1800 Diagonal Road Suite 300, Alexandria, VA 22314 USA. jschmier@exponent.com.

The following articles refer to this text: 2007;33(3):161-164;

2010;36(3):202-215; 2011;37(1):45-53; 2013;39(3):259-267;

2013;39(3):268-275; 2013;39(3):233-240

Key terms: absenteeism; body weight; burden of illness; cost; economic analysis; economics; health care expenditures; obesity; productivity; review; workplace

This article in PubMed: www.ncbi.nlm.nih.gov/pubmed/16539166

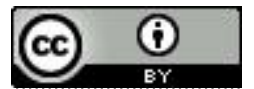




\title{
Cost of obesity in the workplace
}

\author{
by Jordana K Schmier, MA, ${ }^{1}$ Mechelle L Jones, BS, ${ }^{1}$ Michael T Halpern, MD ${ }^{1}$
}

\begin{abstract}
Schmier J, Jones ML, Halpern MT. Cost of obesity in the workplace. Scand J Work Environ Health 2006;32(1):5-11.
As the prevalence of obesity increases, its economic consequences must be understood. This review summarizes published literature on the costs and resource use associated with obesity in the workplace. A Medline literature search was conducted for English-language publications. References from identified articles were also reviewed for relevance. The identified studies evaluated several cost components, including absenteeism, sick leave, disability, injuries, and claims data. Overall, overweight or obese employees had higher sick leave or disability use. Workplace injuries were higher among overweight or obese employees. Health care costs, based on claims data analyses, were also consistently higher for employees with higher body mass indices. Obesity is an important driver of costs in the workplace. These findings quantify the costs and can help employers consider whether to introduce workplace interventions or provide coverage for weight loss programs.
\end{abstract}

Key terms absenteeism; body weight; burden of illness; economic analysis; health care expenditures; productivity; review.

Chronic health conditions, such as migraine and gastroesophageal reflux disease (GERD), are common in the working population in the United States. Employers often bear a substantial burden of the medical care costs incurred by patients with these chronic conditions in the form of insurance premiums and coverage. However, in addition to the direct medical costs, there are other ways in which these chronic conditions affect the financial health of the workplace, particularly through increased absenteeism and decreased productivity. For example, over a 6-month period, almost two-thirds of the patients with asthma in one study reported taking days off from work due to their asthma (1). Even patients with mild GERD symptoms reported decrements in productivity due to symptoms (2). Furthermore, productivity surrounding a work absence may also be affected, as one small study demonstrated measurable decreases in productivity of about $16 \%$ before and after a work absence (3).

Employers are making efforts to identify and contain the costs associated with chronic conditions. Certain conditions that already require regular medical attention are addressed within the context of plan-specific guidelines, formularies, and disease management plans, all of which can be designed to optimize treatment and minimize the impact on the workplace. However, beyond traditional concerns about workplace productivity for conditions such as allergies, asthma, and migraine, interest in the cost impact of obesity in the workplace has arisen. Although it is understood that obesity has a substantial cost in terms of health care resources, there has not been a thorough review of the published literature. This review fills that gap, summarizing what is known from published studies of the estimated cost of obesity in the workplace, including both health-care-related costs and indirect costs such as work loss (absenteeism) and reductions in productivity.

\section{Methods}

A literature search was conducted in Medline, the EBSCOhost Electronic Journals Service, and Questia databases for English-language publications. No year constraints were used, and articles were not limited to the United States. The search is up to date through March 2005. The MeSH headings and key words used included "obesity" or "overweight," and "cost of illness," "cost," "employer health costs," "cost-benefit analysis," or "cost and cost analysis," and "work," "workplace," "business," "industry," "occupations," "employment," or "personnel management." We also crossed "obesity" and "overweight" with "absenteeism," "disability," "presenteeism," "productivity," and "sick leave." For the EBSCOhost search, the results were limited to peerreviewed articles, while the Questia search was limited to journal articles. In addition, the references and tables in each article were reviewed to identify other papers,

1 Exponent Inc, Alexandria, Virginia, United States.

Reprint requests: Jordana Schmier, 1800 Diagonal Road Suite 300; Alexandria, VA 22314 USA. E-mail: jschmier@exponent.com. 
conference proceedings, or consensus workshop publications that were not indexed in Medline. Finally, general Internet searches were conducted, national and international organizations and government health sites being of particular interest. There was no attempt to exclude articles based on differential definitions of overweight or obesity; instead cut-offs for body mass index (BMI) or definitions of obesity are reported in this review for each included study. As the goal of this review was to summarize available information on workplace impacts of obesity, not impacts on obese persons, articles that focused only on wages were not included.

\section{Results}

\section{Workplace impacts}

Absenteeism, sick leave and disability. The extent to which obesity and other chronic conditions affect pro- ductivity can vary by industry and the demographic characteristics of the workforce. Existing studies on productivity and presenteeism have generally not included obesity per se, although some have included its sequelae (eg, hypertension, heart disease, diabetes). More is known about absenteeism. Several studies have shown that overweight and obese employees take more sick leave and spend less time at work than their normal weight counterparts. Table 1 summarizes published studies regarding the relationship impact of obesity on absenteeism and disability.

Multiple studies of sick leave and disability related to obesity have been conducted in Scandinavian countries. Narbro et al reported that obese Swedish women (BMI ranged from 28 to 68 and averaged 39) aged 3059 years took at least 1.5 times more sick leave than the general Swedish population and were more than twice as likely to receive disability pensions (5\% of nonobese women received disability compared with $12 \%$ of obese women) (4). The incremental sick leave and use of

Table 1. Published literature on the relationship between obesity and absenteeism and disability. $(95 \% \mathrm{Cl}=95 \%$ confidence interval, $\mathrm{BMI}=$ body mass index, NA = not assessed, RR = relative risk, US = United States)

\begin{tabular}{|c|c|c|c|c|}
\hline Citation & Population & Definition of obesity & $\begin{array}{l}\text { Difference in absenteeism associated with } \\
\text { overweight and obesity }\end{array}$ & $\begin{array}{l}\text { Difference in disability associated with } \\
\text { overweight and obesity }\end{array}$ \\
\hline $\begin{array}{l}\text { Bungum et al, } \\
2003(9)\end{array}$ & $\begin{array}{l}\text { US municipal } \\
\text { employees, } \\
\text { mean age } \\
41-44 \text { years }\end{array}$ & $\begin{array}{l}\text { Normal }=\mathrm{BMI}<25 \\
\text { overweight }= \\
\mathrm{BMI} 25-30 \text {, obese }= \\
\mathrm{BMI}>30\end{array}$ & $\begin{array}{l}\text { Average annual days absent: normal }=27 \\
\text { (SD 27), overweight } 30 \text { (SD 32), obese }=35 \\
\text { (SD 31); BMI was a significant predictor of } \\
\text { inclusion in the lowest or highest quartile of } \\
\text { absences (OR=1.37) }\end{array}$ & NA \\
\hline $\begin{array}{l}\text { Mansson et al, } \\
1996(6)\end{array}$ & $\begin{array}{l}\text { Swedish men, } \\
\text { median age } \\
48 \text { years }\end{array}$ & $\begin{array}{l}\text { Underweight }=\mathrm{BMI}<20 \text {, } \\
\text { normal }=\mathrm{BMI} 20 \text { to } \\
\leq 25, \text { overweight }= \\
\mathrm{BMI} 25 \text { to } \leq 30 \text {, obese }= \\
\mathrm{BMI} \geq 30\end{array}$ & NA & $\begin{array}{l}\text { Relative risk of receiving disability compared } \\
\text { with that of normal-weight persons (adjusted } \\
\text { for smoking): overweight } 1.3(95 \% \mathrm{Cl} 1.1- \\
1.6) \text {, obese } 2.8 \text { ( } 95 \% \mathrm{CI} 2.2-3.5) \text {; pension- } \\
\text { free survival was significantly longer for } \\
\text { normal versus obese men }\end{array}$ \\
\hline $\begin{array}{l}\text { Narbro et al, } \\
1996 \text { (4) }\end{array}$ & $\begin{array}{l}\text { Swedish wo- } \\
\text { men, age range } \\
30-59 \text { years }\end{array}$ & $\mathrm{BMI}>28.6$ & $\begin{array}{l}\text { Sick leave 1.5-1.9 times greater than that } \\
\text { of general population; overweight women } \\
\text { had lower use of short-term sick leave but } \\
\text { higher use of long-term sick leave than the } \\
\text { general population }\end{array}$ & $\begin{array}{l}\text { Disability pensions } 2.0-2.8 \text { times greater than } \\
\text { for general population }\end{array}$ \\
\hline $\begin{array}{l}\text { Nathell et al, } \\
2002(11)\end{array}$ & $\begin{array}{l}\text { Swedish men } \\
\text { and women, } \\
\text { mean age } \\
40 \text { years }\end{array}$ & $\mathrm{BMI}>30$ & $\begin{array}{l}\text { Higher prevalence of obesity among asth- } \\
\text { matic patients on sick leave compared with } \\
\text { employees on sick leave for nonspecific } \\
\text { pain or controls }(20.7 \%, 13.7 \%, 6.5 \% \text {, } \\
\text { respectively, } P<0.001)\end{array}$ & NA \\
\hline $\begin{array}{l}\text { Rissanen et al, } \\
1990(7)\end{array}$ & $\begin{array}{l}\text { Finnish men } \\
\text { and women, } \\
\text { age range } \\
25-64 \text { years }\end{array}$ & $\begin{array}{l}\mathrm{BMI}>30 \text { (reference } \\
\mathrm{BMI}<22.5)\end{array}$ & NA & $\begin{array}{l}\text { Relative risk of disability for overweight persons } \\
\text { significantly greater for women (RR } 2.0,95 \% \\
\mathrm{Cl} 1.8-2.3 \text { ) and men (RR } 1.5,95 \% \mathrm{Cl} 1.3-1.7) \\
\text { than for reference persons (adjusted for age, } \\
\text { geographic region, occupation, and smoking) }\end{array}$ \\
\hline $\begin{array}{l}\text { Robbins et al, } \\
2002 \text { (22) }\end{array}$ & $\begin{array}{l}\text { US active duty } \\
\text { Air Force per- } \\
\text { sonnel, age } \\
\text { range } 17- \\
60 \text { years }\end{array}$ & $\begin{array}{l}\text { Maximum allowable } \\
\text { weight approximately } \\
\text { BMI } 27.9 \text { for men and } \\
25.0 \text { for women }\end{array}$ & $\begin{array}{l}\text { Exceeding maximum allowable weight } \\
\text { associated with } 28351 \text { lost workdays per } \\
\text { year (USD } 3.5 \text { million annually in 1997) }\end{array}$ & NA \\
\hline $\begin{array}{l}\text { Thompson et } \\
\text { al, } 1998(17)\end{array}$ & $\begin{array}{l}\text { US employees, } \\
\text { age range } \\
25-64 \text { years }\end{array}$ & $\begin{array}{l}\text { Nonobese }=\mathrm{BMI}<25 \\
\text { mildly obese }=\mathrm{BMI} 25- \\
28.9, \text { moderately to se- } \\
\text { vere obese }=\mathrm{BMI} \geq 29\end{array}$ & $\begin{array}{l}\text { Number of annual workdays missed } \\
\text { higher among the moderately to severely } \\
\text { obese compared with nonobese (ranging } \\
\text { from } 5 \% \text { to } 93 \% \text { higher) for all compari- } \\
\text { sons except men } 55-64 \text { years of age ( } 14 \% \\
\text { less than the nonobese) }\end{array}$ & $\begin{array}{l}\text { Disability (defined as self-reported inability to } \\
\text { work) was higher among the moderately to } \\
\text { severely obese than the nonobese (ranging } \\
\text { from } 14 \% \text { to } 140 \% \text { higher) for all compari- } \\
\text { sons except men } 55-64 \text { years of age ( } 7 \% \text { less } \\
\text { than the nonobese) }\end{array}$ \\
\hline $\begin{array}{l}\text { Tucker \& Fried- } \\
\text { man, } 1998 \text { (8) }\end{array}$ & $\begin{array}{l}\text { US employees, } \\
\text { mean age } \\
39 \text { years }\end{array}$ & $\begin{array}{l}\text { Women: obese = body } \\
\text { fat } 30 \% \text { or more; men: } \\
\text { obese = body fat } 25 \% \\
\text { or more age }\end{array}$ & $\begin{array}{l}\text { Obese significantly more likely to have } \\
\text { moderate and high absenteeism (absent } 3- \\
6 \text { and } 7 \text { days in past } 6 \text { months, respectively) } \\
\text { than the nonobese }\end{array}$ & NA \\
\hline
\end{tabular}


disability pensions amounts to approximately USD 300 million (in 1994) annually, reflecting approximately $10 \%$ of the total sick leave and disability cost among Swedish women. A later study by this group also evaluated the impact of surgical treatment for obesity and found that it resulted in more sick days in the first year following surgery, but significantly fewer sick days in subsequent years (5). In a study of Swedish men, Mansson et al also found that the receipt of a disability pension was related to BMI (6). Compared with normal weight men, underweight men had a relative risk of receiving a disability pension of 1.9 [95\% confidence interval (95\% CI) 1.4-2.6], while overweight and obese persons had relative risks of 1.3 (95\% CI 1.1-1.6) and 2.8 (95\% CI 2.2-3.5), respectively. Among employed Finnish obese people, there was a weak association between BMI and mortality, but BMI was also a strong predictor of the early use of disability, women with a BMI of $\geq 30$ being twice as likely as those with a BMI of $\leq 22.5$ to receive disability and men 1.5 times more likely (95\% CI 1.3-1.7) (7).

Studies in the United States have identified obesityrelated sick leave overall and in the military sector. Tucker \& Friedman (8) classified employees as obese if their body fat was $\geq 25 \%$ for men and $\geq 30 \%$ for women, as lean if their body fat was $\leq 15 \%$ for men and $\leq 20 \%$ for women, and average if their body fat was in-between. Employees who were lean or average were also aggregated into a "nonobese" category. Obese employees were significantly more likely to have high or moderate absenteeism (defined as more than seven absences or three to six absences due to illness in the past 6 months, respectively) than the lean or nonobese employee groups, even after control for age, gender, smoking status, and other sociodemographic characteristics.

Bungum et al (9) categorized employees in the municipal workforce of an undisclosed city in the United States into the following three BMI groups: normal (BMI <25), overweight (BMI 25-30), and obese (BMI $>30$ ). Among those in the obese group, absenteeism was highest when compared with that of the normal weight and overweight groups.

A 33-month study of student nurses in the United Kingdom assessed sickness and absenteeism related to weight, smoking, and mental health (10). Relative weight was defined as the BMI divided by the sample mean [21.7 (SD 2.6)]. Absence was assessed as episodes, and sickness was treated as a categorical variable since the distribution was highly skewed. Relative weight demonstrated a curvilinear association with absence, and smoking had additive effects. A high relative weight accompanied by poorer mental health was associated with increased absence. Only $23 \%$ of the study population had a BMI above 23.5. While these data, as reported, cannot speak directly for work loss and obesity, the relationship between relative weight and sickness and absenteeism in this younger population (most students at baseline were between 18 and 25 years of age) is important, as are findings about the interaction between relative weight and mental health.

The use of sick leave may be higher among patients who are obese and also have asthma. One study comparing the prevalence of obesity (BMI $\geq 30$ ) among employees taking sick leave for asthma, for other nonspecific pain, and a general population found the prevalence of obesity to be significantly higher for the asthmatic employees (20.7\% versus $13.7 \%$ and $6.5 \%$, respectively) (11). The presence of asthma was self-reported and then clinically validated. The authors suggested that weight reduction plans may be important to decreasing sick leave associated with asthma.

\section{Workplace injuries}

Several studies have also reported that the rate of workplace injuries is significantly higher among overweight persons. For example, New Zealand patients diagnosed with carpal tunnel syndrome were twice as likely as the general population to be overweight (BMI $\geq 25$ ), and women with carpal tunnel syndrome were twice as likely to be obese (BMI $\geq 30$ ) (12).

An analysis of over 10000 employees working at a Shell Oil manufacturing facility in Texas found that the rate of injuries was higher among employees who were overweight than among the normal-weight population (13). The rate of lower back injuries was 1.42 times higher among overweight employees than among normal-weight employees, and the rate of other, nonback musculoskeletal injuries was 1.53 times higher. The authors suggested that ergonomic improvements, as well as weight reduction programs, would decrease the rate of injuries.

In a survey of over 6000 adults aged 15 years and older in France, there was a significant increase in the rate of occupational injuries with an increased self-reported BMI (BMI categories $\leq 19,20-24$, and $\geq 25$ had annual rates of injury of $2.6 \%, 4.3 \%$, and $5.4 \%$ respectively) (14). This study also found significant differences in the rate of injury by gender, job category, smoking status, use of alcohol and psychotropic drugs, and comorbid conditions, while there were no differences by age. It is difficult to isolate the effect of BMI alone, as there are multiple significant interaction effects and there are significant correlations between BMI and the presence of a disease and smoking status.

In addition to the impact of acute injuries due to obesity, emergent conditions may be more likely to develop into chronic conditions or require more recovery time. Fransen and her colleagues examined predictors of the transition between acute and chronic back pain. 
Employees in New Zealand who filed a new claim for a work-related back injury were identified and followed for 3 months (15). Along with increasing age, functional disability, and radiating leg pain, an above-normal BMI ( $\geq 25)$ was a significant predictor of the transition to chronic back pain. Those who were overweight (BMI 25.1-30) had an odds ratio (OR) of 1.56 (95\% CI 1.082.25) for chronicity when compared with normal-weight employees; those who were obese (BMI >30) had an odds ratio of 1.85 (95\% CI 1.17-2.90). Other personal characteristics, including gender, age, education, smoking status, recent back pain, prior claim of back pain, and general physical fitness, were not significant predictors of chronic back pain. The study also examined psychosocial characteristics, including psychological well-being and role functioning, and workplace characteristics, including amount of lifting, sitting, walking, and driving, and found that many of these factors were also significant predictors of the transition from acute to chronic pain.

Recovery time after an injury may also be longer for those who are overweight or obese. For example, overweight (BMI $\geq 30$ ) French male railway workers were more likely to have absences of 8 days or more in association with an imbalance-related injury than normalweight employees (OR 2.08, 95\% CI 1.04-4.11) (16). However, the occurrence of injury did not differ depending on weight (OR 1.22, 95\% CI 0.83-1.82); smoking and alcohol use, sleep disorders, inactivity, and a request for a job change were associated with the occurrence.

\section{Workplace costs}

The relationship between medical charges and BMI has been examined in several working populations, including the private sector, government agencies, and the military. Studies have used a variety of methods but have consistently found that there is a substantial financial impact, in terms of direct health care costs, increased sick leave, and disability payments, in association with overweight and obesity.

Using data from firms in the private sector in the United States in 1994, Thompson and his colleagues determined that obesity cost businesses USD12.7 billion (in 1994) (17). This sum not only includes health insurance, but also life and disability insurance, as well as paid sick leave for employees between 25 and 64 years of age. Employees with a BMI of $\geq 25$ were considered obese. The proportion of each of these costs attributable to obesity was determined by estimating the prevalence of obesity among age groups (in 10-year increments) and estimating the percentage of medical care costs due to various obesity-related conditions (coronary heart disease, hypertension, stroke, type 2 diabetes, gallbladder disease, hypercholesterolemia, osteoarthritis of the knee, endometrial cancer) that are incurred by employers. The primary assumption made in this calculation (ie, that the cost of a condition is proportional to the rate incidence) should be considered cautiously, as the costs of a specified condition in an obese population may actually be higher than that in a nonobese population due to comorbidities or other complicating factors among obese persons. This study presents costs for those with mild obesity, defined as BMI from 25 to 28.9, and moderate-to-severe obesity, defined as BMI 29 or greater. Type II diabetes was the single highest contributor to workplace spending for obesity. The researchers cautioned that many indirect costs of obesity are accrued by those over the age of 64 years, who are less likely to be working and likely to be using Medicare for a proportion of their medical care costs.

Wang et al (18) grouped over 175000 General Motors (GM) employees into six BMI groups, analyzed medical charges from 1996 and 1997, and expressed these results in USD 2000 (18). The "normal-weight" group (BMI 18.5-24.9) had the lowest annual medical charges (median of USD 2225), with groups who were underweight or overweight or obese (USD 2388-3753, significant at $\mathrm{P}<0.01$ when compared with the "normalweight" group) having higher charges. Charges for the underweight group (median USD 3184) were $43 \%$ higher than those for the normal-weight group; those in the most overweight group (BMI $\geq 40$ ) had charges $69 \%$ higher than those of the normal-weight group. Median charges were used for the medical expenses. Although pharmaceutical costs were included, no analyses were performed by categories of charges (ie, pharmaceutical, inpatient, outpatient). Later work with a subset of this population examined the physical activity levels of these employees, with the objective of determining how much the employer would save if sedentary employees increased their levels of physical activity (19). Employees reported the amount and intensity of weekly physical activities. After adjustment for covariates, the costs were significantly higher by BMI (18.5-24.9, 25.0-29.9, $\geq 30$ ) and by level of physical activity. Within the BMI categories, there was a trend towards lower costs with higher physical activity levels. Drugs represented a higher proportion of total medical costs as BMI increased. Additional analyses of GM employees from 1996 through 2000 also found that the annual average medical costs were higher depending on the BMI, with higher prevalence of diabetes by BMI (20).

Data on health care claims and health risk appraisals of over 3000 employees of First Chicago NBD were evaluated for an assessment of obesity-related costs (21). The employees were classified as obese if their BMI was $\geq 27.8$ for the men and $\geq 27.3$ for the women. The mean 3-year health care cost for obese employees was USD 6822 (in 1996) compared with USD 4496 for 
nonobese employees. This increase in cost was not the result of higher costs for each health care claim, but reflected the greater number of health care claims in comparison with nonobese employees. There were also significant differences in the number and cost of sick days taken. Obese employees used, on the average, more than twice as many sick days as the lower BMI group (mean 8.45 versus 3.73 sick days, $\mathrm{P}<0.001$ ). When the sum of sick day absences over a 6-year period were converted to costs, the obese employees had a cost of USD 863 per person greater than that of the nonobese employees.

Musich and her colleagues evaluated the costs associated with BMI and additional health risks in a population of GM employees (20). Although the study was focused on the prevalence and costs associated with diabetes, the results are still informative. The prevalence of diabetes and the average medical charges increased significantly by BMI group $(<18.5,18.5-24.9,25-29.9$, $30-34.9, \geq 35$ ). The average annual medical charges ranged from USD 3836 (normal weight) to USD 6103 (BMI $\geq 35$ ).

Bungum et al (9) categorized employees in the municipal workforce of an undisclosed city in the United States into the following three BMI groups: normal (BMI <25), overweight (BMI 25-30), and obese (BMI $\geq 30$ ). Those in the obese group experienced higher health care costs than the employees in the overweight group and the normal weight group. In this population, BMI was the only significant predictor of health care costs $(\mathrm{P}=0.009)$, while age, gender, race, education, and smoking status were not significant predictors.

Robbins and his colleagues (22) used a retrospective cohort of personnel who participated in a voluntary health assessment in 1996 and examined the impact of being over the maximum allowable weight on health care expenditures and lost workdays separately by gender. Maximum allowable weight is consistent with a BMI of 27.9 for men and 25.0 for women and may be exceeded on the basis of a demonstration of reasonable attempts to lose weight. The characteristics of the cohort were similar to those of the Air Force overall, and the results were applied to the entire active duty force. The one-fifth of active duty Air Force personnel in the United States who were above their maximum allowable weight were responsible for USD 19.3 million in excess direct medical costs and USD 3.5 million in indirect costs in 1997. Importantly, a validation substudy found that the self-reported height and weight values used to estimate maximum allowable weight for this study were highly correlated $(r>0.92)$ with values obtained during annual fitness testing.

Bradham and his colleagues (23) explored the costs of obesity-related hospitalizations to the United States Navy. This study identified hospitalizations from 1993 through 1998 for conditions that were determined, through a literature review, likely to be caused by overweight or obesity, or to co-exist with either. After costs for this time period were estimated, data on differential costs by demographic and employment level were aggregated to project the annual cost to the Navy. They estimated that there were USD 5.8 million (in 1998) in obesity-related hospitalizations in 1998. Costs per obesity-related admission were estimated to be just over USD 4000, with personnel aged 34 years or less expected to have admissions costing less than USD 3400, while those aged 35 years and older were expected to have more expensive admissions.

\section{Discussion}

Obesity will continue to be an important driver of costs in the workplace, with a unique distinction from other chronic conditions in that it is a condition not generally treated with pharmacological agents. While guideline and formulary-based decisions, such as using nonsedating antihistamines rather than sedating antihistamines, can have an impact on productivity (24), no such simple changes can solve all of the issues related to obesity. However, whether an employer chooses to include interventions for obesity in the arsenal of tools to increase worker productivity, health, and morale can have an impact on the health care costs of the company.

There are several limitations in our review. First, the thresholds for overweight and obesity used across studies differed. While the recommendations of the World Health Organization (WHO) will guide future research, a variety of BMI values has been used to define obesity in previous studies. According to $\mathrm{WHO}$, persons with a BMI of 25 or greater, calculated as weight divided by height squared $\left(\mathrm{kg} / \mathrm{m}^{2}\right)$, are overweight or obese. Although definitions have not been consistent in the past decades, the current WHO classification is now generally accepted globally. Overweight refers to people with a BMI of 25.0 to 29.9, while obese refers to people with a BMI of $\geq 30$, and a BMI of $\geq 40$ is classified as morbid obesity. This classification limits the comparability of the studies somewhat.

When interpreting the studies summarized in this review, one should note that obesity is only one of many issues that can affect workplace costs and productivity; not all of these factors have been controlled in published studies. In addition, there may be relationships between obesity and other workplace issues, such as relations with co-workers (25). Some types of health behavior may also influence workplace costs and productivity or mediate the relationship between obesity and workplace costs. For example, smoking has been shown to affect 
absenteeism (perhaps more so among men than women) (26) and productivity (27). There may also be synergistic effects of smoking and obesity, although such effects have not been confirmed (28). In addition, alcohol abuse is associated with BMI and increased sick leave $(29,30)$, while increased participation in sports and physical activities is generally associated with a lower BMI and less sick leave $(31,32)$.

A variety of work-related characteristics can affect job performance and may be associated with obesity. Work characteristics related to absenteeism include burnout, role clarity, job autonomy, and company policies (33-37). Cultural norms and self-efficacy can also affect job performance (34). Stress, reward-effort balance, and the sedentary nature of the job may also be associated with BMI or weight $(38,39)$. Several analytic techniques, such as structural equation modeling, can help quantify the relationships among health behavior, work characteristics, and work performance. While it is beyond the scope of this review to explore these relationships in detail, future studies should build on what is known and also consider these possible modifiers.

Beyond its impact on employer costs, obesity appears to have negative consequences on wages earned. Baum \& Ford (40) suggest that there is a wage penalty between $0.7 \%$ to $6.3 \%$, with women suffering a larger penalty than men. Several analyses have examined the specific hypotheses about the relationship between BMI and wages (40-42). Some of the issues explored include whether obese people self-select jobs with better health benefits, as well as the converse, that employers offer lower wages due to expectations of higher health care costs; whether there is customer-based discimination that affects success in retail; whether rates of job-related training differs between the obese and nonobese; and whether obesity is related to other health limitations that affect type of job and performance (40-42). Reported findings are sometimes counterintuitive, and more research in the area is needed. When the cost of obesity is considered from the perspective of the employee, this wage differential is clearly an important issue.

The studies reviewed in this paper are largely crosssectional. Studies that have evaluated medical and pharmacy costs have found decreases in costs associated with weight loss over time $(43,44)$. Additional longitudinal studies with interventions for obesity and other conditions, such as that described by Erfurt and his colleagues (45), are necessary to understand the potential for reducing costs in the workplace. With additional information detailing the workplace benefits of decreasing obesity, employers can consider creating environments more conducive to healthy eating and physical activity (eg, changes in cafeteria and vending options, flex-time for people who wish to exercise during the day).
Despite these limitations, some conclusions can be drawn. Compared with employees who are not obese, those who are obese take more sick time and have more injuries and higher health care costs. This difference has been shown across countries and across types of companies. As employers are recognizing the importance of disease management and wellness programs (eg, smoking cessation) for overall employee well-being and health care costs, they may also consider implementing programs to help employees achieve and maintain a healthy weight.

\section{References}

1. Mancuso CA, Rincon M, Charlson ME. Adverse work outcomes and events attributed to asthma. Am J Ind Med. 2003;44(3):236-45.

2. Dean BB, Crawley JA, Schmitt CM, Wong J, Ofman JJ. The burden of illness of gastro-oesophageal reflux disease: impact on work productivity. Aliment Pharmacol Ther. 2003; 17(10):1309-17.

3. Brouwer WB, van Exel NJ, Koopmanschap MA, Rutten FF. Productivity costs before and after absence from work: as important as common? Health Policy. 2002;61(2):173-87.

4. Narbro K, Jonsson E, Larsson B, Waaler H, Wedel H, Sjöström L. Economic consequences of sick-leave and early retirement in obese Swedish women. Int J Obes Relat Metab Disord. 1996;20(10):895-903.

5. Narbro K, Ågren G, Jonsson E, Larsson B, Näslund I, Wedel $\mathrm{H}$, et al. Sick leave and disability pension before and after treatment for obesity: a report from the Swedish Obese Subjects (SOS) study. Int J Obes Relat Metab Disord. 1999; 23(6):619-24.

6. Månsson NO, Eriksson KF, Israelsson B, Rånstam J, Melander A, Rastam L. Body mass index and disability pension in middle-aged men-on-linear relations. Int J Epidemiol. 1996;25(1):80-5.

7. Rissanen A, Heliovaara M, Knekt P, Reunanen A, Aromaa A, Maatela J. Risk of disability and mortality due to overweight in a Finnish population. BMJ. 1990;301(6756):835-7.

8. Tucker LA, Friedman GM. Obesity and absenteeism: an epidemiologic study of 10,825 employed adults. Am J Health Promot. 1998;12(3):202-7.

9. Bungum T, Satterwhite M, Jackson AW, Morrow JR Jr. The relationship of body mass index, medical costs, and job absenteeism. Am J Health Behav. 2003;27(4):456-62.

10. Parkes KR. Relative weight, smoking, and mental health as predictors of sickness and absence from work. J Appl Psychol. 1987;72(2):275-86.

11. Nathell L, Jensen I, Larsson K. High prevalence of obesity in asthmatic patients on sick leave. Respir Med. 2002;96(8):64250.

12. Lam N, Thurston A. Association of obesity, gender, age and occupation with carpal tunnel syndrome. Aust N Z J Surg. 1998;68(3):190-3.

13. Tsai SP, Gilstrap EL, Cowles SR, Waddell LC Jr, Ross CE. Personal and job characteristics of musculoskeletal injuries in an industrial population. J Occup Med. 1992;34(6):606-12.

14. Bhattacherjee A, Chau N, Sierra CO, Legras B, Benamghar L, 
Michaely JP, et al. Relationships of job and some individual characteristics to occupational injuries in employed people: a community-based study. J Occup Health. 2003;45(6):382-91.

15. Fransen M, Woodward M, Norton R, Coggan C, Dawe M, Sheridan N. Risk factors associated with the transition from acute to chronic occupational back pain. Spine. 2002; 27(1):92-8.

16. Gauchard GC, Chau N, Touron C, Benamghar L, Dehaene D, Perrin P, et al. Person characteristics in occupational accidents due to imbalance: a case-control study of the employees of a railway company. Occup Environ Med. 2003;60(5):330-5.

17. Thompson D, Edelsberg J, Kinsey KL, Oster G. Estimated economic costs of obesity to US business. Am J Health Promot. 1998;13(2):120-7.

18. Wang F, Schultz AB, Musich S, McDonald T, Hirschland D, Edington DW. The relationship between National Heart, Lung, and Blood Institute Weight Guidelines and concurrent medical costs in a manufacturing population. Am J Health Promot. 2003;17(3):183-9.

19. Wang F, McDonald T, Champagne LJ, Edington DW. Relationship of body mass index and physical activity to health care costs among employees. J Occup Environ Med. 2004;46(5):428-36.

20. Musich S, Lu C, McDonald T, Campagne LJ, Edington DW. Association of additional health risks on medical charges and prevalence of diabetes within body mass index categories. Am J Health Promot. 2004;18(3):264-8.

21. Burton WN, Chen CY, Schultz AB, Edington DW. The economic costs associated with body mass index in a workplace. $\mathrm{J}$ Occup Environ Med. 1998;40(9):786-92.

22. Robbins AS, Chao SY, Russ CR, Fonseca VP. Costs of excess body weight among active duty personnel, US Air Force, 1997. Mil Med. 2002;167(5):393-7.

23. Bradham DD, South BR, Saunders HJ, Heuser MD, Pane KW, Dennis KE. Obesity-related hospitalization costs to the US Navy, 1993 to 1998. Mil Med. 2001;166(1):1-10.

24. Cockburn IM, Bailit HL, Berndt ER, Finkelstein SN. When antihistamines go to work. Bus Health. 1999;17(3):49-50.

25. Pronk NP, Martinson B, Kessler RC, Beck AL, Simon GE, Wang P. The association between work performance and physical activity, cardiorespiratory fitness, and obesity. J Occup Environ Med. 2004;46(1):19-25.

26. Leigh JP. Smoking, self-selection, and absenteeism. Q Rev Econ Finance. 1995;35(4):365-86.

27. Halpern MT, Shikiar R, Rentz AM, Khan ZM. Impact of smoking status on workplace absenteeism and productivity. Tob Control. 2001;10(3):233-8.

28. Leigh JP, Berger MC. Effects of smoking and being overweight on current earnings. Am J Prev Med. 1989;5(1):8-14.

29. Breslow RA, Smothers BA. Drinking patterns and body mass index in never smokers: National Health Interview Survey, 1997-2001. Am J Epidemiol. 2005;161(4):368-76.

30. Cunradi CB, Greiner BA, Ragland DR, Fisher J. Alcohol, stress-related factors, and short-term absenteeism among urban transit operators. J Urban Health. 2005;82(1):43-57.

31. Hu FB, Li TY, Colditz GA, Willett WC, Manson JE. Television watching and other sedentary behaviors in relation to risk of obesity and type 2 diabetes mellitus in women. JAMA 2003;289(14):1785-91.

32. van den Heuvel SG, Boshuizen HC, Hildebrandt VH, Blatter BM, Ariëns GA, Bongers PM. Effect of sporting activity on absenteeism in a working population. Br J Sports Med. 2005;39(3):e15.

33. Moreau M, Valente F, Mak R, Pelfrene E, de Smet P, De Backer G, et al. Occupational stress and incidence of sick leave in the Belgian workforce: the Belstress study. J Epidemiol Community Health. 2004;58(6):507-16.

34. Schroer CA, Janssen M, van Amelsvoort LG, Bosma H, Swaen GM, Nijhuis FJ, et al. Organizational characteristics as predictors of work disability: a prospective study among sick employees of for-profit and not-for-profit organizations. J Occup Rehabil. 2005;15(3):435-45.

35. Toppinen-Tanner S, Ojajarvi A, Väänänen A, Kalimo R, Jappinen $\mathrm{P}$. Burnout as a predictor of medically certified sickleave absences and their diagnosed causes. Behav Med 2005;31(1):18-27.

36. Väänänen $\mathrm{A}$, Toppinen-Tanner $\mathrm{S}$, Kalimo R, Mutanen $\mathrm{P}$, Vahtera J, Peiró JM. Job characteristics, physical and psychological symptoms, and social support as antecedents of sickness absence among men and women in the private industrial sector. Soc Sci Med. 2003;57(5):807-24.

37. Väänänen A, Kalimo R, Toppinen-Tanner S, Mutanen P, Peiró JM, Kivimaki M, et al. Role clarity, fairness, and organizational climate as predictors of sickness absence: a prospective study in the private sector. Scand J Public Health. 2004;32(6):426-34.

38. Ishizaki M, Morikawa Y, Nakagawa H, Honda R, Kawakami $\mathrm{N}$, Haratani T, et al. The influence of work characteristics on body mass index and waist to hip ratio in Japanese employees. Ind Health. 2004;42(1):41-9.

39. Kouvonen A, Kivimaki M, Cox SJ, Cox T, Vahtera J. Relationship between work stress and body mass index among 45,810 female and male employees. Psychosom Med. 2005;67(4):577-83.

40. Baum CL, Ford WF. The wage effects of obesity: a longitudinal study. Health Econ. 2004;13(9):885-99.

41. Cawley J. What explains race and gender differences in the relationship between obesity and wages? Gender Issues. 2003;21(3):30-49.

42. Cawley J. The impact of obesity on wages. J Human Res. 2004;39:451-74.

43. Edington DW, Yen LT, Witting P. The financial impact of changes in personal health practices. J Occup Environ Med. 1997;39(11):1037-46.

44. Ågren G, Narbro K, Näslund I, Sjöström L, Peltonen M. Long-term effects of weight loss on pharmaceutical costs in obese subjects. A report from the SOS intervention study. Int J Obes Relat Metab Disord. 2002;26(2):184-92.

45. Erfurt JC, Foote A, Heinrich MA. The cost-effectiveness of worksite wellness programs for hypertension control, weight loss, smoking cessation, and exercise. Pers Psychol. 1992;45:5-27.

Received for publication: 25 April 2005 